\title{
Comparison of Dig-Labeled PCR, Nested PCR, and ELISA for the Detection of Clavibacter michiganensis subsp. sepedonicus in Field-Grown Potatoes
}

\author{
I.-M. Lee, L. A. Lukaesko, Molecular Plant Pathology Laboratory, Agricultural Research Service, U.S. Department of \\ Agriculture, Beltsville, Maryland 20705; and C. J. M. Maroon, Agdia Inc., 30380 County Road 6, Elkhart, IN 46514
}

\begin{abstract}
Lee, I.-M., Lukaesko, L. A., and Maroon, C. J. M. 2001. Comparison of dig-labeled PCR, nested PCR, and ELISA for the detection of Clavibacter michiganensis subsp. sepedonicus in fieldgrown potatoes. Plant Dis. 85:261-266.

The sensitivity of digoxigenin- (dig-) labeled polymerase chain reaction (PCR) was compared with nested PCR and enzyme-linked immunosorbent assay (ELISA) for the detection of the potato ring rot bacterium, Clavibacter michiganensis subsp. sepedonicus, in seed potatoes and stem tissues. The bacterial DNA was extracted from chopped tuber or stem tissue by a modified hot alkaline DNA extraction method. C. michiganensis subsp. sepedonicus specific DNA sequence was amplified by dig-labeled PCR with the primer pair CMSIF1/CMSIR1 previously designed based on the insertion element IS1121 of C. michiganensis subsp. sepedonicus. Dig-labeled PCR products were then blotted on a nylon membrane and the signal was detected by a colorimetric assay using alkaline phosphatase. The new assay procedure has a detection sensitivity close to that of nested PCR and simplicity of the standard ELISA procedure commonly used commercially. The dig-labeled PCR assay was more sensitive than ELISA and can be used to detect $C$. michiganensis subsp. sepedonicus in symptomless field potato tubers.
\end{abstract}

Additional keywords: Clavibacter michiganensis subsp. insidiosus, threshold values

Bacterial ring rot disease, caused by the gram-positive bacterium $C$. michiganensis subsp. sepedonicus, is readily spread by planting infected seed potatoes. Zero tolerance levels have been set in the United States, Canada, and the European Union in an effort to eradicate the disease (26). Despite zero tolerance levels that have existed for 50 years in the United States, potato ring rot remains one of the most important pathogens in U.S. seed potato lots. The difficulty in controlling the spread of $C$. michiganensis subsp. sepedonicus may be due to latent infection that escapes detection $(8,9,16,27,32)$.

Strong efforts have been made to develop efficient and sensitive assays for commercial detection of $C$. michiganensis subsp. sepedonicus in seed potato. Serological assays, particularly enzyme-linked immunosorbent assay (ELISA), are the most commonly used methods for indexing of potato seed lots. The popularity of serological assays for the indexing of potatoes is largely due to their simplicity of operation and their applicability in large-

Corresponding author: I.-M. Lee

E-mail: imlee@asrr.arsusda.gov

Accepted for publication 20 October 2000

Publication no. D-2000-1204-02R

This article is in the public domain and not copyrightable. It may be freely reprinted with customary crediting of the source. The American Phytopathological Society, 2001. scale indexing $(10,12,16,33)$. One major drawback of serological assays, however, is false positives caused by cross reaction of antibodies with plant debris or nonpathogenic bacteria $(6,7,10,21)$. Although cross reactions can be greatly reduced by use of specific monoclonal antibodies, they remain a problem $(11,16,20,22)$. Furthermore, antigenic variation among the strains of C. michiganensis subsp. sepedonicus has increased the difficulty in developing an antibody with the same detection efficiency for all strains $(2,10,11)$. An additional problem inherent with ELISA is the need to set an appropriate threshold level to compensate for the nonspecific reactions, which can lessen the sensitivity of the test $(16,33)$. Confirmation of C. michiganensis subsp. sepedonicus in positive samples from serological assays with an eggplant bioassay is often necessary (3). Because eggplant bioassay is laborious and time-consuming, it is unsuitable for largescale use. In addition, some eggplants may be subject to the same latent infection with C. michiganensis subsp. sepedonicus as potato (10). Currently, confirmation is often carried out by the more specific immunofluorescence assay (IFA) using monoclonal antibodies to a somatic antigen of the bacteria $(10,11)$. Although significantly improved sensitivity and specificity have been reported, IFA is not completely free of the problems of cross-reactivity with saprophytic bacteria $(16,20)$.

DNA hybridization has been suggested as an alternative method to index seed potato lots $(15,17,22,23,28,33)$. Although highly specific probes have been developed, the sensitivity of the assay remains a problem. DNA-based polymerase chain reaction (PCR) assays developed recently are a promising alternative to current assays $(14,28-31,33,34)$. C. michiganensis subps. sepedonicus-specific oligonucleotide primers have been designed from $16 \mathrm{~S} / 23 \mathrm{~S}$ rRNA intergenic spacer region (20), selected chromosomal regions and the 1.3-kb insertion element IS1121, a highly repetitive segment of DNA that is present in plasmid pCS1 and integrated into the chromosome of $C$. michiganensis subsp. sepedonicus $(4,5,24,25)$. In a previous study, nested PCR with two sets of primer pairs designed from the IS1121 insertion element was used to detect $C$. michiganensis subsp. sepedonicus in infected field potato tubers and symptomless tubers from supermarkets (18). The nested PCR assay proved to be a highly sensitive method for detecting very low titers of $C$. michiganensis subsp. sepedonicus (18). The tediousness of nested PCR, however, makes largescale use difficult. A practical, ultrasensitive method for the detection of C. michiganensis subsp. sepedonicus is needed.

In this study, a simple detection method was developed involving an alkaline extraction of $C$. michiganensis subsp. sepedonicus DNA (36), digoxigenin- (dig-) labeled PCR, and colorimetric detection. The method is simple, specific, and highly sensitive. As such, dig-labeled PCR is highly suitable to confirm serological tests for detecting ring rot bacteria and has the potential to be adapted for large-scale indexing of potato seed lots. This method was compared with ELISA and nested PCR using identical tuber and stem samples. A preliminary report on this study was published previously (19).

\section{MATERIALS AND METHODS}

Bacterial strains and sources of potato tubers. C. michiganensis subsp. sepedonicus-infected potato tubers and stem samples were harvested from field plots in North Dakota where mature potato plants were grown from seed potatoes inoculated with $10^{8} \mathrm{CFU} / \mathrm{ml}$ population of $C$. michiganensis subsp. sepedonicus strains AS1, Wi2, and OFF3, and from seedlings steminoculated with $10^{8} \mathrm{CFU} / \mathrm{ml}$ population of C. michiganensis subsp. sepedonicus strain AS1. The stem samples exhibited typical symptoms but most tuber samples had no 
apparent symptoms. Seed potato and stem samples (cv. Russett Burbank) infected with $C$. michiganensis subsp. sepedonicus strains AS1, Wi2, and OFF3 were used to compare the three methods of DNA extraction. Pure cultures of $C$. michiganensis subsp. sepedonicus strain AS1, and $C$. michiganensis subsp. insidiosus strain 239, used as references in the restriction fragment length polymorphism (RFLP) analysis, and C. michiganensis subsp. sepedonicus non-mucoid strain $\mathrm{P} 45$ were provided by B. D. Mogen (University of Wisconsin, River Falls). The bacterial cultures were maintained in NBY medium (35). DNA was extracted per the procedure for prepartion of genomic DNA from bacteria described by Ausubel et al. (1).

DNA extraction of $C$. michiganensis subsp. sepedonicus from infected potato tissues. The efficiencies of two simplified DNA extraction methods were evaluated by comparison to the lengthier modified Dellaporta method described previously (13,18). C. michiganensis subsp. sepedonicus-infected stems and tubers obtained from North Dakota fields were used. Each tuber was surface sterilized and dried. A unit of approximately $2 \mathrm{~g}$ of infected stem or tuber tissue (from the stolon end) was cut and chopped with a razor blade in a sterile petri plate and then rinsed in $2 \mathrm{ml}$ of grinding buffer ( $\mathrm{pH}$ 7.6) consisting of 95 $\mathrm{mM} \mathrm{K} \mathrm{HPO}_{4} \cdot \mathrm{H}_{2} \mathrm{O}, 30 \mathrm{mM} \mathrm{KH_{2 }} \mathrm{PO}_{4}, 10 \%$ sucrose, $0.15 \%$ bovine serum albumin fraction $\mathrm{V}, 2 \%$ polyvinylpyrrolidone 10 , and $0.53 \%$ ascorbic acid. In order to precipitate starch grains, the crude extract was collected in a microcentrifuge tube and set at room temperature for $10 \mathrm{~min}$. A unit of $600 \mu \mathrm{l}$ of the extract (supernatant) was collected and equally divided into three microcentrifuge tubes. After centrifugation at $16,000 \times g$ for $10 \mathrm{~min}$ in a microcentrifuge (Eppendorf Scientific, Inc., Westbury, NY), the supernatant was removed and the pellet was subjected to one of three methods of DNA extraction. In method one, the pellet containing $C$. michiganensis subsp. sepedonicus was resuspended in $25 \mu \mathrm{l}$ of $0.25 \mathrm{~N} \mathrm{NaOH}$ and boiled for $2 \min$ (36). The lysate was neutralized with $25 \mu \mathrm{l}$ of $0.25 \mathrm{~N} \mathrm{HCl}$ and $12.5 \mu \mathrm{l}$ of $0.5 \mathrm{M}$ Tris- $\mathrm{HCl}$ (pH 8.0) containing $0.1 \%$ ( vol/vol) Tween 20 then centrifuged for $2 \mathrm{~min}$ at $16,000 \times g$ to eliminate the debris. In the second method, the pellet was resuspended in 25 $\mu \mathrm{l}$ of $0.25 \mathrm{~N} \mathrm{NaOH}$ and neutralized with 25 $\mu \mathrm{l}$ of $0.25 \mathrm{~N} \mathrm{HCl}$. The neutralized sample was precipitated in 0.6 volume of isopropanol for $20 \mathrm{~min}$ at $-20^{\circ} \mathrm{C}$. After precipitation, the sample was centrifuged for 20 $\min$ at $16,000 \times g$. The pellet was resuspended in $62.5 \mu \mathrm{l}$ of Tris-EDTA (TE) $(\mathrm{pH}$ 7.5) buffer. For the third method, the pellet was resuspended in $100 \mu \mathrm{l}$ of TEN buffer (10 mM Tris, $6 \mathrm{mM} \mathrm{NaCl}, 1 \mathrm{mM}$ EDTA, $\mathrm{pH} 8.0$ ) containing $4 \mathrm{mg}$ of lysozyme per $\mathrm{ml}$, and the DNA was extracted as described previously (18). The final pellet was resuspended in $62.5 \mu \mathrm{l}$ of TE ( $\mathrm{pH} 7.5)$. Serial dilutions $\left(10^{-1}\right.$ to $\left.10^{-3}\right)$ of each DNA extract obtained by the three extraction methods were prepared using sterile deionized water. One $\mu \mathrm{l}$ of the diluted DNA extract was used as template in direct PCR amplification (with primer pair CMSIF1/CMSIR1) as described below to compare efficacy of each extraction method for detecting $C$. michiganensis subsp. sepedonicus. For the remaining experiments, DNA extractions were performed according to the hot alkaline extraction method described above.

Comparative sensitivities of ELISA and PCR. The sensitivities of ELISA and PCR-based procedures in detecting $C$. michiganensis subsp. sepedonicus were evaluated with a mix of pure cultures of $C$. michiganensis subsp. sepedonicus and potato stem or tuber extracts. Two sets of serial dilutions of fresh cultures of AS1 and P45 were prepared by mixing $200 \mu \mathrm{l}$ of bacterial culture with $800 \mu$ l of either potato stem or tuber extract. A unit of $200 \mu \mathrm{l}$ of each dilution were used in ELISA conducted with the PathoScreen Kit (Agdia, Elkhart, IN) which is based on a monoclonal antibody for $C$. michiganensis subsp. sepedonicus described by De Boer et al. (12). A unit of $200 \mu \mathrm{l}$ of tissue extract collected from each sample as described above was centrifuged at $16,000 \times g$ for 10 min. The pellet was resuspended in $1 \mathrm{ml}$ of MEB Extract Buffer (Agdia) and incubated for $10 \mathrm{~min}$ at room temperature. One hundred $\mu \mathrm{l}$ of each dilution were pipetted into anti-C. michiganensis subsp. sepedonicus antibody coated wells and incubated overnight at $4^{\circ} \mathrm{C}$ in a humid box. Application of the second anti- $C$. michiganensis subsp. sepedonicus antibody and the enzyme conjugate, and subsequent detection using p-nitrophenyl phosphate (PNP) substrate, were carried out according to the manufacturer's instructions. The absorbance at $405 \mathrm{~nm}\left(\mathrm{~A}_{405}\right)$ was measured using a Titertek Multiskan MCC/340 MK II plate reader (Flow Laboratories, Mississauga, Ont.) 1 and $6 \mathrm{~h}$ after adding PNP substrate.

For PCR, $1 \mathrm{ml}$ of each dilution was centrifuged and DNA was extracted from the resulting pellet. One $\mu \mathrm{l}$ of the DNA dilution ( $1 \mu \mathrm{l}$ DNA: $9 \mu$ HPLC grade water) was used as template in PCR which was performed with 38 cycles using AmpliTaq gold as described previously (18). Nested PCR (38 cycles) was performed using the primer pair CMSIF1/CMSIR1 (5' - tgt act cgg cca tga cgt tgg-3'/5'- tac tgg gtc atg acg ttg gt-3') followed by the primer pair CMSIF2/CMSIR2 (5'- tcc cac ggt aat gct cgt ctg- $3^{\prime} / 5^{\prime}$ - gat gaa ggg gtc aag ctg gtc- $3^{\prime}$ ) as described previously (18). PCR products amplified with CMSIF1/CMSIR1 were diluted 1:30 in sterile deionized water and $1 \mu \mathrm{l}$ was used in the nested PCR. PCR products were analyzed by electrophoresis through $1 \%$ agarose gel followed by staining with ethidium bromide and visualization of DNA bands using a UV transilluminator. The bacterial concentration in each dilution was estimated by agar plating using NBYmedium (35).

Nested PCR and dig-labeled PCR. A unit of two grams of tissue from a $C$. michiganensis subsp. sepedonicus (strain AS1) infected stem and tuber was chopped and rinsed in $2 \mathrm{ml}$ of grinding buffer. A unit of $200 \mu \mathrm{l}$ of the extract was collected and centrifuged. The pellet was subjected to the hot alkali extraction method described above. A series of dilutions $\left(10^{-1}\right.$ to $10^{-7}$ ) of the neutralized DNA extract (a total of $62.5 \mu \mathrm{l}$ ) were used as templates for PCR. Direct and nested PCR were performed with 35 cycles using AmpliTaq Gold (PE Applied Biosystems, Foster City, CA) as described above.

The same DNA extracts tested by nested PCR were used as templates for diglabeled PCR using the primer pair CMSIF1/CMSIR1. Dig-labeled PCR was performed in a reaction mixture containing $160 \mu \mathrm{M}$ each of dATP, dCTP and dGTP, $152 \mu \mathrm{M}$ of dTTP, $8 \mu \mathrm{M}$ of dig-11-dUTP, $1 \times$ PCR buffer (final concentration of $10 \mathrm{mM}$ Tris- $\mathrm{HCl}, \mathrm{pH} 8.3,100 \mathrm{mM} \mathrm{KCl}, 3 \mathrm{mM}$ $\mathrm{MgCl}_{2}, 0.002 \%$ [wt/vol] gelatin), $1.0 \mu \mathrm{M}$ of each primer, formamide (final concentration, 3\%), and AmpliTaq Gold. Thirtyfive cycles were conducted with the following parameters: $94^{\circ} \mathrm{C}$ for $1 \mathrm{~min}(12 \mathrm{~min}$ in the first cycle), $62^{\circ} \mathrm{C}$ for $2 \mathrm{~min}, 72^{\circ} \mathrm{C}$ for $3 \mathrm{~min}$ (10 $\mathrm{min}$ in the last cycle). Diglabeled PCR products were detected either by agarose gel electrophoresis or by dot blot colorimetric detection method.

Colorimetric detection of dig-labeled PCR products. Dig-labeled PCR products were denatured at $99^{\circ} \mathrm{C}$ for $10 \mathrm{~min}$ and then submerged immediately in ice. A unit of $6 \mu \mathrm{l}$ of the denatured products was blotted onto a positively charged nylon membrane $(0.2 \mu \mathrm{m}$ pore size $)$ (ICN, Irvine, CA) then crosslinked $\left(120,000 \mu \mathrm{l} / \mathrm{cm}^{2}\right)$ to the membrane using Stratalinker (Stratagene, La Jolla, CA). Dig-labeled PCR products were detected by treating the membrane with anti-dig Fab fragments conjugated to alkaline phosphatase and signal was generated using colorimetric substrates nitroblue tetrazolium (NBT) and 5-bromo-4-chloro3-indolyl phosphate (BCIP) according to the manufacturer's recommendations (Boehringer-Mannheim, Indianapolis, IN). To get the maximum signal the blotted membranes were developed overnight.

Detection of $C$. michiganensis subsp. sepedonicus in field samples by nested PCR, dig-labeled PCR and ELISA. Ten tuber and four stem samples (cv. Red, Russett Burbank, or Norchip) infected with $C$. michiganensis subsp. sepedonicus strain AS1 were used to compare dig-labeled PCR, nested PCR, and ELISA. All stem samples exhibited typical symptoms. The majority of tuber samples had no symptoms. Stems and tubers were surfaced ster- 
ilized and dried at room temperature. A unit of two grams of stem or tuber tissue was cut from each sample and rinsed in 2 $\mathrm{ml}$ of grinding buffer. A unit of $400 \mu \mathrm{l}$ of the extract was collected and equally divided into two microcentrifuge tubes. One tube was set aside for ELISA and the other for DNA extraction. ELISA was performed as described above. To extract the DNA, the tube was centrifuged at $16,000 \times g$ for $10 \mathrm{~min}$. The pellet was subjected to hot alkaline lysis as described above resulting in DNA extract with a final volume of 62.5 $\mu \mathrm{l}$. The diluted DNA extract (1:10 in sterile deionized water) was used as a template in nested PCR and dig-labeled PCR. All PCR in this experiment were performed with 35 cycles. The experiment was repeated once.

Restriction fragment length polymorphism analysis of PCR products. The CMSIF1/CMSIR1 PCR products amplified from DNA extracts of pure cultured $C$. michiganensis subsp. sepedonicus strain AS1 and C. michiganensis subsp. insidiosus strain 239 and DNA extracts from a potato stem and a seed potato infected with C. michiganensis subsp. sepedonicus strain AS1 were analyzed by RFLP analysis. A unit of four microliters of each PCR product were digested separately with HaeIII, HpaII, HhaI, and AluI following the manufacturer's recommendations. Restriction products were separated by electrophoresis on a $6.0 \%$ polyacrylamide gel followed by staining with ethidium bromide.
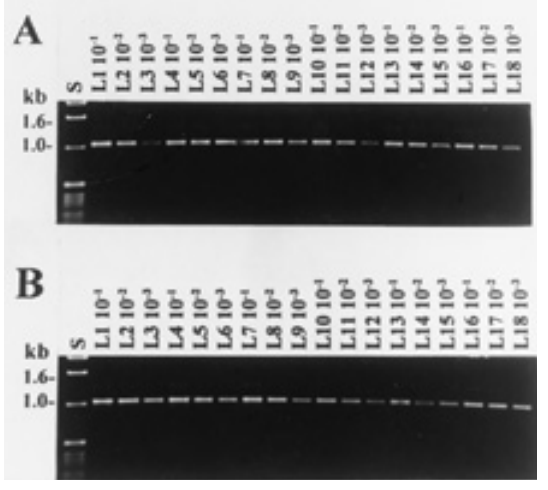

Fig. 1. Comparison of polymerase chain reaction (PCR) amplifications for the detection of potato ring-rot bacterium Clavibacter michiganensis subsp. sepedonicus with DNA templates prepared by modified Dellaporta, hot alkaline, and alkaline/precipitation methods. DNA extracts, which were diluted from $10^{-1}$ to $10^{-3}$ and used as templates, were prepared from stem and tuber samples of Russet Burbank cultivar infected with a C. michiganensis subsp. sepedonicus strain, AS1, OFF3 or Wi2. PCR was performed by using the primer pair CMSIF1/CMSIR1 designed based on the IS1121 insertion sequence from the bacterium. A, L1 to L9 and L10 to L18, stem and tuber samples, respectively, infected with strain AS1; B, L1 to L9 and L10 to L18, tuber samples infected with strains OFF3 and Wi2, respectively. DNA templates prepared by: the Dellaporta method, L1 to L3; the hot alkaline method, L4 to L6 and L13 to L15; and the alkaline/precipitation method, L7 to L9 and L16 to L18.

\section{RESULTS}

Method of DNA extraction and detection of $C$. michiganensis subsp. sepedonicus. C. michiganensis subsp. sepedonicus was detected in all tuber and stem (Fig. 1A and B) samples by PCR using templates prepared by the two simple alkaline lysis extraction methods and modified Dellaporta method. The efficiencies of the two simple DNA extraction procedures were comparable to the lengthier modified Dellaporta method. PCR using diluted $\left(10^{-}\right.$ $1,10^{-2}$, and $10^{-3}$ ) DNA templates prepared from the three extraction procedures yielded similar amount of products.

Comparative sensitivities of ELISA and PCR. The sensitivity of PCR-based procedures was much greater than that of ELISA (Table 1). ELISA sensitivity depended on strains of $C$. michiganensis subsp. sepedonicus. The mucoid strain AS1 was detected by ELISA when present as low as $10^{5}$ to $10^{6} \mathrm{CFU} / \mathrm{ml}$ (with an average of $3.9 \times 10^{5} \mathrm{CFU} / \mathrm{ml}$ ) of tuber extract or $10^{4}$ to $10^{6} \mathrm{CFU} / \mathrm{ml}$ (with an average of $7.6 \times 10^{4} \mathrm{CFU} / \mathrm{ml}$ ) of stem extract. It was less sensitive, however, in detecting the non-mucoid strain $\mathrm{P} 45$, which had dilution end points of $10^{7}$ to $10^{8} \mathrm{CFU} / \mathrm{ml}$ (with an average of $5.3 \times 10^{7} \mathrm{CFU} / \mathrm{ml}$ ) of tuber extract or $10^{6}$ to $10^{7} \mathrm{CFU} / \mathrm{ml}$ (with an average of $2.1 \times 10^{7} \mathrm{CFU} / \mathrm{ml}$ ) of stem extract. On the other hand, strain AS1 was detected by PCR (with 38 cycles) when present as low as $260 \mathrm{CFU} / \mathrm{ml}$ of tuber extract or 52 $\mathrm{CFU} / \mathrm{ml}$ of stem extract. Strain P45 was detected when present at $891 \mathrm{CFU} / \mathrm{ml}$ of stem or tuber extract.

Comparative sensitivities of nested PCR and dig-labeled PCR. Although direct (first run) PCR (with 35 cycles) using primer pair CMSIF1/CMSIR1 allowed for the detection of $C$. michiganensis subsp. sepedonicus in a $10^{-3}$ (stem) or $10^{-4}$ (tuber) dilution of the DNA extract (Fig. 2A and 2B), nested PCR using the primer pair CMSIF1/CMSIR1 followed by the primer pair CMSIF2/CMSIR2 allowed for the detection of the pathogen in as high as a $10^{-6}$ dilution of the DNA extract (Fig.
$2 \mathrm{C}$ and $\mathrm{D})$. The sensitivity was one to two orders of magnitude greater than direct PCR. With 35 cycles dig-labeled PCR detected $C$. michiganensis subsp. sepedonicus in as high as a $10^{-4}$ dilution of the DNA extract when electrophoresis was employed to detect the PCR products (data not shown). The sensitivity of detection of dig-labeled products on a dot blotted nylon membrane increased 10 - to 100 -fold in comparison to the electrophoretic detection on an agarose gel (Fig. 2E and F).

Efficacy of nested PCR, dig-labeled PCR, and ELISA for detection of $C$. michiganensis subsp. sepedonicus. Twelve of 14 samples (Fig. 3A) were positive for $C$. michiganensis subsp. sepedonicus using nested PCR, while only 5 of 14 were positive by direct PCR (35 cycles) (Table 2). Results obtained using diglabeled PCR (with colorimetric detection of PCR products) were in agreement with the results obtained using nested PCR, but weaker signals were obtained by diglabeled PCR (Fig. 3B, Table 2). The sensitivity for detecting $C$. michiganensis subsp. sepedonicus by ELISA, using potato-tissue extracts from identical samples used in dig-labeled PCR and nested PCR assays was comparable to that found by direct PCR (35 cycles). When plates were read 70 min after incubation with PNP, only five of 14 samples scored positive and one scored borderline positive based on a threshold value of $A_{405}=0.1$. The ELISA values of the samples tested ranged from 0.005 to 0.535 (Table 1 ). The results were similar when plates were read $6 \mathrm{~h}$ after incubation.

Confirmation of target organism by RFLP analysis of PCR-amplified products. RFLP analyses of direct PCR products $(1.1 \mathrm{~kb})$ (amplified using the CMS1F1/CMS1R1 primer pair) from $C$. michiganensis subsp. sepedonicus and $C$. michiganensis subsp. insidiosus revealed distinct restriction digestion patterns for all enzymes used in the analysis, indicating substantial sequence heterogeneity between the two PCR products (Fig. 4). Two

Table 1. Sensitivity comparison of enzyme-linked immunosorbent assay (ELISA), direct polymerase chain reaction (PCR), and nested PCR for detecting Clavibacter michiganensis subsp. sepedonicus in potato extracts

\begin{tabular}{|c|c|c|c|c|}
\hline \multirow[b]{3}{*}{ Extract/strain } & \multicolumn{4}{|c|}{ Threshold level $(\mathrm{CFU} / \mathrm{ml})^{\mathrm{a}}$} \\
\hline & \multicolumn{2}{|c|}{ ELISA } & \multicolumn{2}{|c|}{ PCR with AmpliTaq Gold } \\
\hline & $1 h^{b}$ & $6 h^{b}$ & Direct $(38 \text { cycles })^{c}$ & Nested (38 cycles) \\
\hline \multicolumn{5}{|l|}{ Tuberd } \\
\hline AS-1 & $1.9 \times 10^{6}$ & $3.9 \times 10^{5}$ & 260 & 52 \\
\hline P45 & $3.0 \times 10^{8}$ & $5.3 \times 10^{7}$ & 891 & 891 \\
\hline \multicolumn{5}{|l|}{ Stem $^{\mathrm{d}}$} \\
\hline AS-1 & $8.0 \times 10^{5}$ & $7.6 \times 10^{4}$ & 52 & 52 \\
\hline P45 & $6.0 \times 10^{7}$ & $2.1 \times 10^{7}$ & 891 & 178 \\
\hline
\end{tabular}

a Threshold level refers to the dilution end point below which the bacteria could not be detected. The bacteria were diluted in potato stem or tuber extract.

b Time when ELISA readings were taken after addition of the substrate. The values of CFU/ml were calculated based on the average of three experiments.

c Direct PCR was performed with or without dig-labeled dUTP.

d Source of potato extract. 
representative PCR products (amplified with CMSIF1/CMSIR1) of DNA extracts obtained from stems and tubers infected with $C$. michiganensis subsp. sepedonicus strain AS1 had identical restriction digestion patterns to the $C$. michiganensis subsp. sepedonicus reference for all enzymes.

\section{DISCUSSION}

ELISA and IFA are the most widely used techniques for indexing seed potatoes for $C$. michiganensis subsp. sepedonicus. ELISA's simplicity allows for its use in large-scale indexing of commercial seed potatoes destined for import and export. Because of its limited sensitivity and lack of specificity, however, ELISA cannot readily detect very low titers of $C$. michiganensis subsp. sepedonicus in symptomless potato tubers. Gudmestad et al. (16) reported that sensitivity of ELISA or IFA reached an acceptable level (>80\%) only when populations of ring rot bacteria in the samples were $\geq 10^{6} \mathrm{CFU} / \mathrm{g}$ fresh weight. The limit of ELISA for the detection of $C$. michiganensis subsp. sepedonicus has been reported to be in the range of $1 \times 10^{5} / \mathrm{ml}$ to $5 \times 10^{6} / \mathrm{ml}$ cells (10). Available ELISA kits will fail to detect some latent infections.

Most commercial ELISA kits for the detection of the potato ring rot bacteria are equipped with more specific monoclonal antibodies that react to the extracellular polysaccharide (EPS) of $C$. michiganensis subsp. sepedonicus. The detection efficiency depends on the amount of EPS produced by each bacterial strain (10). In this study, the commercially available ELISA kit could detect a mucoid strain (AS1) when populations of ring rot bacteria were $3.91 \times 10^{5} \mathrm{CFU} / \mathrm{ml}$ in tuber extract and $7.62 \times 10^{4} \mathrm{CFU} / \mathrm{ml}$ in stem extract. The efficiency of ELISA tests in our hands was comparable to or higher than those reported previously $(2,16)$. The same ELISA test, however, was insensitive in detecting a non-mucoid strain (P45), which proved undetectable at levels below $2 \times 10^{7}$ $\mathrm{CFU} / \mathrm{ml}$ in either tuber or stem extracts. The lack of sensitivity of ELISA in this case may be attributed to the insufficient secretion of EPS by the non-mucoid strain, P45. Our results confirmed the report by Baer and Gudmestad (2) that ELISA was insensitive to detect non-mucoid strains of C. michiganensis subsp. sepedonicus.

These observations show a major limitation of ELISA that necessitates the development of an alternative assay that is sensitive and independent of factors that vary among the different strains of $C$. michiganensis subsp. sepedonicus. PCR

\section{B}

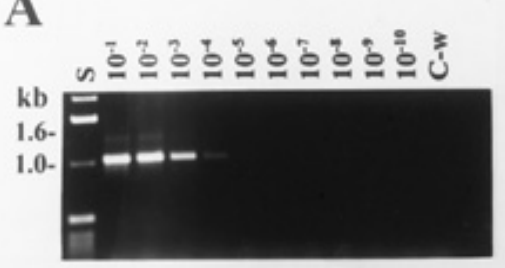

C

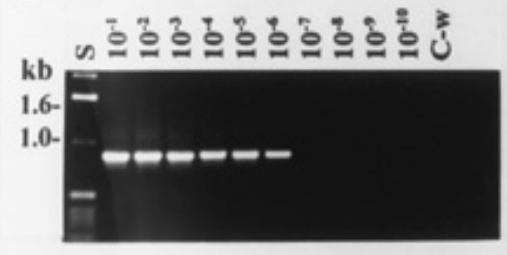

E

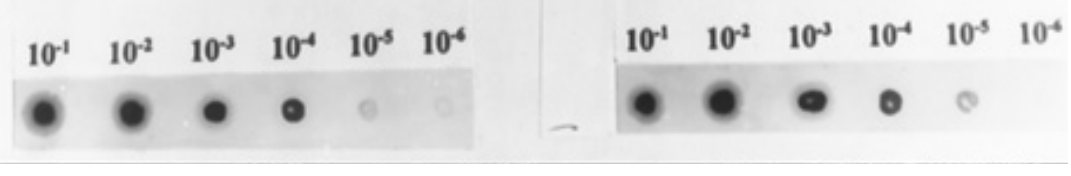

Fig. 2. Comparison of nested polymerase chain reaction (PCR) and dig-labeled PCR assays for the detection of the potato ring rot bacterium Clavibacter michiganensis subsp. sepedonicus. Serial dilutions of the DNA extracts prepared from stem $(\mathbf{A}, \mathbf{C}$, and $\mathbf{E})$ and tuber $(\mathbf{B}, \mathbf{D}$, and $\mathbf{F})$ samples infected with strain AS1 were used as templates in the different PCR assays. Nested PCR was performed first (direct PCR) with the primer pair CMSIF1/CMSIR1 (35 cycles) followed by the nested primer pair CMSIF2/CMSIR2 (35 cycles) and the PCR products were detected by electrophoresis through a $1 \%$ agarose gel. Dig-labeled PCR was performed with the primer pair CMSIF1/CMSIR1. In dig-labeled PCR , dTTP and dig-11-dUTP used at 20:1 were incorporated in the PCR mixture. The dig-labeled PCR products were dot-blotted on a positively charged nylon membrane and detected with colorimetric substrates NBT and BCIP. A, and B, showed the detection efficacy by direct PCR; C, and D, the detection efficacy by nested PCR; E, and F, the detection efficacy by dig-labeled PCR assay. Lane S, $1 \mathrm{~kb}$ DNA ladder; lane C-w, water control. involving primers that can detect all strains of the ring-rot bacteria is the logical and practical alternative. Nested PCR was demonstrated to be the most sensitive among the DNA-based assays developed recently and more specific than ELISA or IFA (18). By applying nested PCR, tests performed previously (18) and in this study revealed that an average of $10 \%$ of symptomless commercial tubers (presumably $C$. michiganensis subsp. sepedonicus-free) were infected with low titers of ring-rot bacteria that apparently were undetected through the seed potato certification program currently implemented. This indicates that nested PCR could facilitate the screening of imported germplasm and potato-tissue cultures for the presence of the pathogen. Such a technique, however, is too cumbersome for use in large-scale indexing of commercial seed potatoes.

In this study, an uncomplicated assay characterized by simple alkaline DNA extraction and PCR was developed for the detection of C. michiganensis subsp. sepedonicus. Using AmpliTaq Gold, direct PCR with 38 cycles was 1,450 - to 41,000 fold more sensitive than ELISA in detecting both mucoid and non-mucoid strains, respectively. The sensitivity could be enhanced further by dig-labeled PCR and colorimetric detection of PCR products using substrates NBT and BCIP to replace
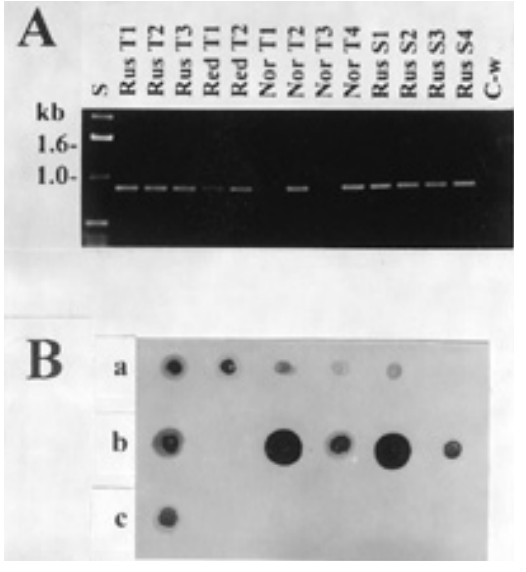

Fig. 3. Comparison of nested polymerase chain reaction (PCR) and dig-labeled PCR assays for the detection of the bacterial ring rot bacterium in field-grown potatoes. Ten tuber and four stem samples collected from three potato cultivars Russet Burbank, Red, and Norchip, infected with Clavibacter michiganenesis subsp. sepedonicus strain AS1 were used for comparison of the sensitivity of the two assays. Nested PCR and dig-labeled PCR were performed as described in Fig. 2. Diluted $\left(10^{-1}\right)$ DNA extracts were used as templates. A, Nested PCR products on 1\% agarose gel; Rus = Russet Burbank, Nor = Norchip, T1 to T4, tuber samples, S1 to S4, stem samples, lane S, $1 \mathrm{~kb}$ DNA standard, and C-w, water control. B, Dig-labeled PCR products dot-blotted on nylon membrane and detected with colorimetric substrates NBT and BCIP. Row a: samples, Rus T1 to T3, Red T1, Red T2, and Nor T1; row b: samples, Nor T2 to T4 and Rus S1 to S3; row c: samples, Rus S4 and C-w. 
the highly sensitive yet tedious nested PCR. Dig-labeled PCR assay was comparable to nested PCR in sensitivity and specificity. In addition to the advantage of not having to perform a second PCR, the detection of $C$. michiganensis subsp. sepedonicus can be accomplished by colorimetric visualization of dot-blotted dig-labeled PCR products. In this study, when diglabeled PCR was performed only with 35 cycles, colorimetric visualization had detection sensitivity about one to two orders of magnitude greater than that of ethidium bromide staining of electrophoresed gels containing PCR products. Furthermore, dot blotting can be manually or automatically operated. Blotted membranes can be developed immediately or indefinitely stored until a sufficient number is reached for batch processing. With pre-mixed PCR reagents, the whole detection operation should not take more than 2 days.

Indexing of seed potato for C. michiganensis subsp. sepedonicus by dig-labeled PCR was accomplished by using the CMSIF1/CMSIR1 primer pair. This primer pair was designed based on the insertion element IS1121, a highly repeated (>50 repeats) DNA segment present in the chromosome of all strains of C. michiganensis subsp. sepedonicus including those which do not contain plasmids $(4,5,24,25)$. The sensitivity of PCR using CMSIF1/CMSIR1 is expected to be greater than that using other primers designed to target DNA fragments that occur as a single copy in the bacterial chromosome.

The reliability of dig-labeled PCR assay depends on the specificity of the primers designed. Some primers designed previously for the detection of $C$. michiganensis subsp. sepedonicus may not be useful for dig-labeled PCR assay. For example, PCR using a primer pair designed from the re- peated sequence contained on a 1.078-kb SmaI fragment of the plasmid pCS1 was shown to be equally sensitive for detecting C. michiganensis subsp. sepedonicus, but it also detected other pathogens of potato including Erwinia carotovora (33). Thus, such a primer set is not useful for diglabeled PCR assay. In contrast, the primer pair CMSIF1/CMSIR1 detected both $C$. michiganensis subsp. sepedonicus and $C$. michiganensis subsp. insidiosus but not other plant bacterial pathogens tested (18). Furthermore, C. michiganensis subsp. insidiosus is associated with alfalfa and has not been found naturally in potatoes. In potato samples CMSIF1/CMSIR1 should specifically detect $C$. michiganensis subsp. sepedonicus. If necessary, results can be verified by RFLP analysis of nested PCR products amplified using the second primer pair, CMSIF2/CMSIR2 (18).

In comparison to the standard ELISA currently used commercially, dig-labeled PCR assay described in this paper is comparable in terms of its simplicity of operation and can be improved and adapted for large-scale applications. Dig-labeled PCR assay is much more sensitive than ELISA. Positive results obtained by ELISA are confirmed by IFA. The reliability of IFA, however, is highly dependent on specificity of the antibodies. On the other hand, the confirmation of target pathogen detected by dig-labeled PCR can be readily accomplished by RFLP analysis of PCR products. The most significant feature of the diglabeled PCR developed in this study is its ultrasensitivity in detecting latent $C$. michiganensis subsp. sepedonicus infection. Initially the dig-labeled PCR with 35 cycles resulted in a number of positive samples (visible PCR products on the gel) equal to that obtained by ELISA (Table 2). By increasing the reaction cycles from 35 to 38 , however, the sensitivity of diglabeled PCR was further improved to nearly that of nested PCR (Table 1).

Serological tests currently used in indexing symptomless stem or potato tuber samples can detect ring rot bacteria when titers are as low as $7.6 \times 10^{4} \mathrm{CFU} / \mathrm{ml}$ (this study) or about $10^{6} \mathrm{CFU} / \mathrm{g}$ fresh weight (16). Symptomless samples with titers

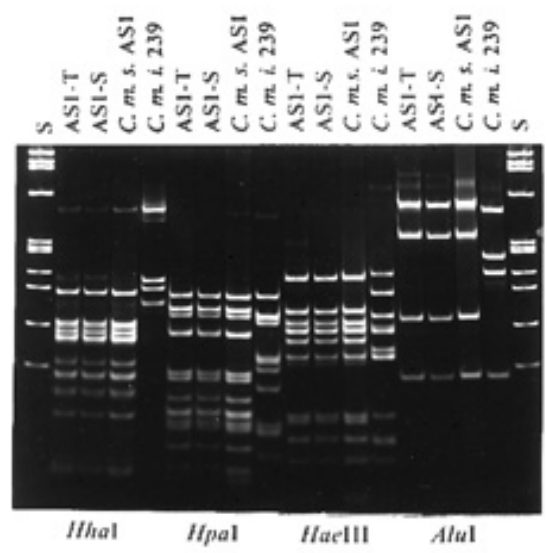

Fig. 4. Restriction fragment length polymorphism analysis of insertion sequence IS1121 of potato ring rot bacterium Clavibacter michiganensis subsp. sepedonicus amplified with the primer pair CMSIF1/CMSIR1. Template DNAs were prepared from two reference bacterial strains, Clavibacter michiganensis subsp. sepedonicus AS1 (C.m.s. AS1) and Clavibacter michiganensis subsp. insidiosus 239 (C.m.i. 239) and samples of stem and tuber infected with strain C.m.s. AS1. Polymerase chain reaction products were digested with restriction enzymes Hha I, HpaII, HaeIII, and AluI and DNA fragments were separated by $6 \%$ polyacrylamide gel electrophoresis. Lane S contains a $\phi X 174$ RF I DNA HaeIII digest: the fragment sizes in base pairs (from top to bottom) are $1,353,1,078,872$, $603,310,281,271,234,194,118$, and 72 .

Table 2. Comparison of enzyme-linked immunosorbent assay (ELISA), dig-labeled polymerase chain reaction (PCR) assay, and nested PCR for the detection of bacterial ring rot pathogen of potato

\begin{tabular}{|c|c|c|c|c|c|}
\hline \multirow[b]{2}{*}{ Cultivar $^{\mathrm{c}}$} & \multirow[b]{2}{*}{$\operatorname{ELISA}\left(A_{405}\right)^{\mathrm{d}}$} & \multicolumn{2}{|c|}{ Dig-labeled PCR ${ }^{a}$} & \multicolumn{2}{|c|}{ Nested PCR ${ }^{\mathbf{b}}$} \\
\hline & & Gel elec. & Colorimetric & Direct & Nested \\
\hline Rus T1 & $0.019(-)$ & $-^{\mathrm{e}}$ & $+^{\mathrm{e}}$ & - & + \\
\hline Rus T2 & $0.079\left(0^{c}\right)$ & - & + & - & + \\
\hline Rus T3* & $0.023(-)$ & - & + & - & + \\
\hline Red T1* & $0.024(-)$ & - & + & - & + \\
\hline Red T2 & $0.007(-)$ & - & + & - & + \\
\hline Red T3 & $0.005(-)$ & - & - & - & $\mathrm{ND}^{\mathrm{e}}$ \\
\hline Nor T1 & $0.037(-)$ & - & - & - & - \\
\hline Nor T2 & $0.005(-)$ & - & + & - & + \\
\hline Nor T3 & $0.010(-)$ & - & - & - & - \\
\hline Nor T4 & $0.535(+)$ & + & + & + & + \\
\hline Rus S1* & $0.287(+)$ & + & + & + & + \\
\hline Rus S2* & $0.270(+)$ & + & + & + & + \\
\hline Rus S3* & $0.140(+)$ & + & + & + & + \\
\hline Rus S4* & $0.263(+)$ & + & + & + & + \\
\hline
\end{tabular}

a Dig-labeled PCR (35 cycles) was performed with the primer pair CMSIF1/CMSIR1. The PCR products were detected by gel electrophoresis (gel elect.) through $1 \%$ agarose gel or by the colorimetric method with substrates NBT and BCIP.

${ }^{b}$ Nested PCR was performed with the primer pair CMSIF1/CMSIR1 (direct) followed by the primer pair CMSIF2/CMSIR2 (nested). PCR products were detected by gel electrophoresis.

${ }^{\mathrm{c}}$ Cultivars: Rus = Russet Burbank; Nor $=$ Norchip; $\mathrm{T}=$ tuber, $\mathrm{S}=$ stem; samples with symbol $*$ were symptomatic and all other samples were symptomless.

d ELISA threshold of $A_{405}=0.1$.

${ }^{\mathrm{e}}-=$ negative $;+=$ positive $; 0=$ borderline positive, $\mathrm{ND}=$ not determined. 
lower than these threshold values, however, will pass inspection. Symptomless seed potatoes with latent $C$. michiganensis subsp. sepedonicus may take two or more generations to develop symptomatic plants when planted (27), but they will be potential new sources of inoculum for bacterial ring rot. The lack of highly sensitive assays that can be used commercially to detect very low titers of the ring rot bacterium present in symptomless seed potatoes may account for continued spread of potato ring rot (J. H. Mcbeath, University of Alaska, Fairbanks, personal communication). The use of pathogen-free seed potatoes in commercial production is one of the most efficient avenues to achieve the goal of eradicating this devastating disease. To this end, the dig-labeled PCR assay developed in this study may serve as a more sensitive means for the detection of $C$. michiganensis subsp. sepedonicus and consequently aid in reaching the goal of eliminating potato ring rot disease. The sensitivity of dig-labeled PCR assay is believed to be comparable to recently developed BIOPCR using an automated real-time fluorescence detection system (30). The BIO-PCR assay, however, requires an expensive PCR detection system, and the assay, which involves laborious culturing, takes 3 to 5 days. We are currently adapting the diglabeled PCR assay such that it can be used to detect $C$. michiganensis subsp. sepedonicus in composite sizes prescribed in potato certification programs. In the meantime, the dig-labeled PCR procedure, in combination with RFLP analysis of PCR products, is one of the most reliable and simple confirmatory tests available and may be applied to small composited sample sizes and for screening tissue culture materials.

\section{ACKNOWLEDGMENTS}

We thank N. C. Gudmestad, North Dakota State University, for providing infected potatoes.

\section{LITERATURE CITED}

1. Ausubel, F. M., Brent, R., Kingston, R. E., Moore, D. D., Seidman, J. G., Smith, J. A., and Stuhl, K. 1987. Current protocols in molecular biology. Wiley Interscience, New York, NY.

2. Baer, D., and Gudmestad, N. C. 1993. Serological detection of nonmucoid strains of Clavibacter michiganensis subsp. sepedonicus in potato. Phytopathology 83:157-163.

3. Bishop, A. L., and Slack, S. A. 1987. Effect of inoculum dose and preparation, strain variation, and plant growth conditions on the eggplant bioassay for bacterial ring rot. Am. Potato J. 64:227-234.

4. Chuang, L.-Y. 1994. Insertion sequencetargeted approaches to detection and differentiation of strains of Clavibacter michiganensis subspecies sepedonicus. $\mathrm{Ph} \mathrm{D}$. diss. North Dakota State University, Fargo.

5. Clark, M. C., and Lawrence, C. H. 1986. Char- acterization of a plasmid in isolates of Corynebacterium sepedonicum. Can. J. Microbiol. 32:617-622.

6. Crowley, C. F., and De Boer, S. H. 1982. Nonpathogenic bacteria associated with potato stems cross-react with Corynebacterium sepedonicum antisera in immunofluorescence. Am. Potato J. 59:1-8.

7. De Boer, S. H. 1982. Cross-reaction of Corynebacterium sepedonicum antisera with $C$. insidiosum, C. michiganese, and an unidentified coryneform bacterium. Phytopathology 72:1474-1478.

8. De Boer, S. H., Janse, J. D., Stead, D. E., Van Vaerenbergh, J., and McKensie, A. R. 1992. Detection of Clavibacter michiganensis subsp. sepedonicus in potato stems and tubers grown from seed pieces with various levels of inoculum. Potato Res. 35:207-216.

9. De Boer, S. H., and McCann, M. 1989. Determination of population densities of Corynebacterium sepedonicum in potato stem during the growing season. Phytopathology 79:946951.

10. De Boer, S. H., Stead, D. E., Alivizatos, A. S., Janse, J. D., Van Vaerenbergh, J., De Haan, T. L., and Mawhinney, J. 1994. Evaluation of serological tests for detection of Clavibacter michiganensis subsp. sepedonicus in composite potato stem and tuber samples. Plant Dis. 78:725-729.

11. De Boer, S. H., and Wieczorek, A. 1984. Production of monoclonal antibodies to Corynebacterium sepedonicum. Phytopathology 74:1431-1434.

12. De Boer, S. H., Wieczorek, A., and Kummer, A. 1988. An ELISA test for bacterial ring rot of potato with a new monoclonal antibody. Plant Dis. 72:874-878.

13. Dellaporta, S. L., Wood, J., and Hicks, J. B. 1983. A plant DNA minipreparation: version II. Plant Mol. Biol. Rep. 1:19-21.

14. Drennan, J., Slack, S., Westra, A., Collmer, A., Gudmestad, N., and Oleson, A. 1994. Specific detection of Clavibacter michiganensis subsp. sepedonicus with the polymerase chain reaction. Phytopathology 84:1087.

15. Firrao, G. 1990. Cloned diagnostic probe for the detection of Clavibacter michiganensis subsp. sepedonicus. EPPO Bull. 20:207-213.

16. Gudmestad, N. C., Baer, D., and Kurowski, C. J. 1991. Validating immunoassay test performance in the detection of Corynebacterium sepedonicum during the growing season. Phytopathology 81:475-480.

17. Johansen, I. E., Rasmussen, O. F., and Heide, M. 1989. Specific identification of Clavibacter michiganensis subsp. sepedonicum by DNAhybridization probes. Phytopathology 79:10191023.

18. Lee, I.-M., Bartoszyk, I. M., Gundersen, D. E., Mogen, B., and Davis, R. E. 1996. Nested PCR assays for ultrasensitive detection of potato ring rot bacterium, Clavibacter michiganensis subsp. sepedonicus. Appl. Environ. Microbiol. 63: 2625-2630.

19. Lee, I.-M., and Lukaesko, L. A. 1998. An improved procedure for rapid and sensitive detection of the potato ring rot bacterium Clavibacter michiganensis subsp. sepedonicus in commercial potato tubers. Phytopathology 88:S52.

20. Li, Xiang, and De Boer, S. H. 1995. Selection of polymerase chain reaction primers from an RNA intergenic spacer region for specific detection of Clavibacter michiganensis subsp. sepedonicus. Phytopathology 85:837-842.
21. Miller, H. J. 1984. Cross-reactions of Corynebacterium sepedonicum antisera with soil bacteria associated with potato tubers. Neth. J. P1 Path. 90:23-28.

22. Mills, D., Russell, B. W., and Hanus, J. W. 1997. Specific detection of Clavibacter michiganensis subsp. sepedonicus by amplification of three unique DNA sequences isolated by subtraction hybridization. Phytopathology 87:853-861.

23. Mirza, M. S. 1993. Specific 16S ribosomal RNA targeted oligonucleotide probe against Clavibacter michiganensis subsp. sepedonicus. Can. J. Microbiol. 39:1029-1034.

24. Mogen, B. D., Oleson, A. E., Sparks, R. B., Gudmestad, N. C., and Secor, G. A. 1988. Distribution and partial characterization of pCS1, a highly conserved plasmid present in Clavibacter michiganense subsp. sependonicum. Phytopathology 78:1381-1386.

25. Mogen, B. D., Oleson, H. R., Sparks, R. B., Gudmestad, N. C., and Olson, A. E. 1990. Genetic variation in strains of Clavibacter michiganense subsp. sepedonicum: polymorphisms in restriction fragments containing a highly repeated sequence. Phytopathology 80:90-96

26. Munro, J. 1978. Seed potato improvement in Canada. Can. Plant Dis. Surv. 58:26-28.

27. Nelson, G. A. 1982. Corynebacterium sepedonicum in potato: Effect of inoculum concentration on ring rot symptoms and latent infection. Can. J. Plant Pathol. 4:129-133.

28. Rademaker, J. L. W., and Janse, J. D. 1994. Detection and identification of Clavibacter michiganensis subsp. sepedonicus and Clavibacter michiganensis subsp. michiganensis by nonradioactive hybridization, polymerase chain reaction, and restriction enzyme analysis. Can. J. Microbiol. 40:10071018

29. Rossen, L., Noskov, P., Holmstrom, K., and Rasmussen, O. F. 1992. Inhibition of PCR components of food samples, microbial diagnostic assays and DNA-extraction solution. Int. J. Food Microbiol. 17:37-45.

30. Schaad, N. W., Berthier-Schaad, Y., Sechler, A., and Knorr, D. 1999. Detection of Clavibacter michiganensis subsp. sepedonicus in potato tubers by BIO-PCR and automated real- time fluorescence detection system. Plant Dis. 83:1095-1100.

31. Schneider, B. J., Zhao, J. L., and Orser, C. S. 1993. Detection of Clavibacter michiganensis subsp. sepedonicus by DNA amplification. FEMS Microbiol. Lett. 109:207-212.

32. Shepard, J. F., and Claflin, L. E. 1975. Critical analyses of the principle of seed potato certification. Annu. Rev. Phytopathol. 13:271-293.

33. Slack, S. A., Drennan, J. L., and Westra, A. A G. 1996. Comparison of PCR, ELISA, and DNA hybridization for the detection of Clavibacter michiganensis subsp. sepedonicus in field-grown potatoes. Plant Dis. 80:519-524.

34. Tsai, Y. L., and Olson, B. H. 1992. Detection of low numbers of bacterial cells in soils and sediments by polymerase chain reaction. Appl. Environ. Microbiol. 58: 754-757.

35. Vidaver, A. 1967. Synthetic and complex media for the rapid detection of fluorescence of phytopathogenic pseudomonads: Effect of the carbon source. Appl. Microbiol. 15:15231534.

36. Zhang, S., and Goodwin, P. H. 1997. Rapid and sensitive detection of Xanthomonas fragariae by simple alkaline DNA extraction and polymerase chain reaction. J. Phytopathol. 145:267-270 